\title{
A womanist theological engagement of triple patriarchy and its implications on (Ejagham) women's liberation
}

\begin{tabular}{|c|c|}
\hline \multicolumn{2}{|c|}{$\begin{array}{l}\text { Authors: } \\
\text { Tabe J.O.E. Benoni-Wang }{ }^{1} \text { ( } \\
\text { Vuyani S. Vellem }{ }^{1} \uparrow \text { (1) }\end{array}$} \\
\hline \multicolumn{2}{|c|}{$\begin{array}{l}\text { Affiliations: } \\
{ }^{1} \text { Department of Systematic } \\
\text { and Historical Theology, } \\
\text { Faculty of Theology and } \\
\text { Religion, University of } \\
\text { Pretoria, Pretoria, South Africa }\end{array}$} \\
\hline \multicolumn{2}{|c|}{$\begin{array}{l}\text { Research Project Registration: } \\
\text { Project Leader: V.S. Vellem } \\
\text { Project Number: } 04425030\end{array}$} \\
\hline \multicolumn{2}{|c|}{$\begin{array}{l}\text { This is research that is part of } \\
\text { the project, 'Social Cohesion', } \\
\text { that was directed by Prof Dr. } \\
\text { Vuyani Vellem of the } \\
\text { Department of Systematic } \\
\text { and Historical Theology, } \\
\text { Faculty of Theology and } \\
\text { Religion, University of } \\
\text { Pretoria. }\end{array}$} \\
\hline \multicolumn{2}{|c|}{$\begin{array}{l}\text { Corresponding author: } \\
\text { Tabe Benoni-Wang, } \\
\text { tabejennet@yahoo.com }\end{array}$} \\
\hline \multicolumn{2}{|c|}{$\begin{array}{l}\text { Received: } 06 \text { Jun. } 2019 \\
\text { Accepted: } 18 \text { Dec. } 2019 \\
\text { Published: } 20 \text { Apr. } 2020\end{array}$} \\
\hline \multicolumn{2}{|c|}{$\begin{array}{l}\text { How to cite this article: } \\
\text { Benoni-Wang, T.J.O.E. \& } \\
\text { Vellem, V.S., 2020, } \\
\text { 'A womanist theological } \\
\text { engagement of triple } \\
\text { patriarchy and its } \\
\text { implications on (Ejagham) } \\
\text { women's liberation', HTS } \\
\text { Teologiese Studies/ } \\
\text { Theological Studies 76(1), } \\
\text { a5601. https://doi.org/ } \\
\text { 10.4102/hts.v76i1.5601 }\end{array}$} \\
\hline \multicolumn{2}{|c|}{$\begin{array}{l}\text { Copyright: } \\
\text { (c) 2020. The Authors. } \\
\text { Licensee: AOSIS. This work } \\
\text { is licensed under the } \\
\text { Creative Commons } \\
\text { Attribution License. }\end{array}$} \\
\hline \multicolumn{2}{|l|}{ Read online: } \\
\hline 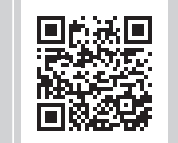 & $\begin{array}{l}\text { Scan this QR } \\
\text { code with your } \\
\text { smart phone or } \\
\text { mobile device } \\
\text { to read online. }\end{array}$ \\
\hline
\end{tabular}

This article seeks through Ejagham women's experience in the ritual dances of Ngbokondem and Moninkim to engage the notion of patriarchal control of African women's sexuality in 'female genital mutilation' discourses as postulated by second-wave feminist theorists such as Daly, Koedt, Hosken and so on. A firmly based patriarchy threatens culture, sexuality and identity; the article shows how women use varied coping mechanisms, including aid schemes, sexual insurgency and even breaking of bodies to define their place and identity in a patriarchal society. However, some Ejagham women's practices are themselves laced with patriarchal violence where women postulate as main participants. The article coins the term 'triple patriarchy' to capture this phenomenon. It portrays how Ejagham women, who are interrogating domination, also act in ways that reinforce patriarchy. Using womanist theological lens as the hermeneutic framework, the article concludes that women initiation practices are the foundations through which women grasp the meanings of Christian initiation rituals such as baptism, eucharist, marriage and so on. Hence, they should not be destroyed but fine-tuned; for there is more about the women's practices that need to be engaged than labelled.

Keywords: patriarchy; 'female genital mutilation'; Nkim e Nkim; triple patriarchy; womanism; initiation practices; 'bottom power' insurgency; liberation.

\section{Introduction}

The practice of Nkim e Nkim, a cultural rite which has been globally described as 'female genital mutilation', remains a concern for the Ejagham area in Cameroon and the global community. Attempts to address the practice in Ejagham community are replete with controversies. Ejagham is one of the many communities in Africa and Cameroon where the practice has been conducted for over a century. The origin of the practice largely remains a matter of speculation. Earliest sources such as Talbot (1926) and Ruel (1969) show that the practice endured long before and after colonisation; it is almost a century old. This article uses a womanist theological hermeneutical lens to suggest that global, national and local perspectives applied to address the practice amongst the Ejagham have, for the most part, been skewed, thus leading largely to criticism rather than dialogical and engaging attempts in addressing the practice.

Globally, second-wave feminism's (SWF) preliminary attempts to address the practice from a Global North perspective could be considered stereotypic, based on works like Gyn/Ecology where Daly (1976) describes the practice as 'African genital mutilation' with untold barbarity. Feminist theorists such as Koedt (1973), Daly (1976) and Hosken (1978) from the mid-20th century focused primarily on sex domination, through patriarchy as the primary motivation for the practice in other parts of the world (Oba 2008:5). This notion could be symptomatic of the global power systems that influence global trends and discourses. The study holds that the genital mutilation discourses amongst Ejagham community have not been engaged enough. Some prevailing realities have been overlooked that give the practice more meaning in the Ejagham context.

The concept of triple patriarchy is basically an engagement of patriarchy in a new (third) form, that is, as Ejagham women's struggle and agency within patriarchal context. Initiation practices are communing spaces for women, where they create bonding and community that is meaningful for life, culture, sexuality and identity. However, they are becoming spaces of domination as well as commodification of bodies where some women oppress others to even sustain patriarchy. Using womanist theological hermeneutical lens to engage the present contextual realities within Nkim e Nkim, the article expresses the idea that Ejagham women's experiences are survival strategies within Nkim culture which includes even 'bottom power'. Womanist theological hermeneutics sees their experience in light of women's resistance against patriarchy, as well as agency which is a phenomenal occurrence in history (cf. Machera 2004; Onor 2017; Wipper 1985).

Note: $\uparrow, 1968-2020$. 
The article is organised as follows: firstly, it presents the Ejagham woman and the persistence of her practice of Nkim e Nkim in the Moninkim club and Ngbokondem dance as a conscious contestation against labels of patriarchy through acceptance and / or resistance syndrome (Pemunta 2012:223ff.). Secondly, it employs womanist theological hermeneutics to engage the concept of triple patriarchy as a reproduction of patriarchy in a context of impoverishment, and how this reshapes women initiation spaces in Ejagham community. Lastly, it discusses the implications of the concept on health, sexuality, spirituality and identity.

\section{Context of the research and study methods}

The Ejagham is a Bantu-speaking community situated in Manyu division of the South West region of Cameroon. They are culturally minded people blessed with different cultural practices that inform their daily realities. Nkim e Nkim and other religio-cultural practices have shaped the lives of women. We carried out two major visits for field research from 08 December 2015 to 29 February 2016 and from 05 February 2017 to 09 March 2017. Here, we enquired on women initiation practices of Nkim e Nkim as our locus of study. However, we were interested in other initiation practices with sexual implications that go alongside Nkim (in Ngbokondem/Moninkim clubs) to shape women's lives such as $\mathrm{Mbi}$ ebe (literarily translated marriage money), Nkekwet [widowhood] rituals and burial of Ejagham women. These are all religious initiation rites, which shape Ejagham women's understanding of other Christian initiation practices such as baptism, eucharist, marriage and so on.

Ejagham Njemaya, made up of three clans, is still widely known for the practice of Nkim e Nkim. The last campaign to combat the practice in the area was launched by the Canadian embassy in Cameroon, in cooperation with Chantier D'Appui, de Loisirs, de Bricolage des Lapinos (CALBRIL), a non-governmental organisation (NGO) concerned with women and the girl child's welfare. This stop campaign was chaired by the representative for the Canadian Ambassador in Cameroon from Yaounde from 26 to 28 January 2016. Sources of data collection included individual and collective qualitative interviews through questionnaires, video and audio recordings, photographs, council files and maps, news items on paper and radio, field notes and reports.

\section{Ejagham women's initiation spaces as religious spaces and sexual agency}

\section{The Ngbokondem and Moninkim club}

Although women were from a colonial mindset judged as weak, inferior and peripheral in development (Onor 2017:24), the colonial enterprise in Ejagham community took interest in women's cultural associations because of their strong initiation rites and rituals, some of which governed the community (Hamilton 2013). Women associations included
'Moninkim', Ngbokondem, Ekpa, Nnenwa and so on (Bayen 2016:11). These are all ancestral cults that have endured and sustained the entire cultural community politically and spiritually. Two of these women's associations, Moninkim club and the Ngbokondem cult, have had immense influence on women's religious status, as well as sexuality and identity. This is the result of their attachment to the Nkim sexual ritual which has been described by the international community and especially some second-wave feminist theorists as 'genital mutilation' and patriarchal domination of women's sexuality.

The persistence of the practice in Ejagham still remains a concern for the area and the global community.

Global and national perspectives applied to address the practice amongst the Ejagham have, for the most part, been skewed, thus leading largely to criticism rather than dialogical and engaging attempts in addressing the practice.

Based on the significance of the practices on Ejagham women's spiritual worldview, one notices that this was not sufficiently engaged particularly by second-wave feminist theorists' interventions in the genital mutilation discourses in Africa.

Globally, SWF's preliminary attempts to address the practice from a Global North perspective could be considered stereotypic. The works of Koedt (1968, 1973), Hosken (1976) and Daly (1978) significantly condemned African people and labelled the practice as barbaric rather than engaged with it. These feminist theorists from the mid-20th century focused primarily on sex domination, through patriarchy as the primary motivation for the practice in other parts of the world (Oba 2008:5). Just emerging from a background of struggle against patriarchal suppression of the clitoris in the orgasm debates, these theorists attributed practices modifying the clitoris in Africa to patriarchy and its suppression of sexual pleasure in women. Daly (1978:160), in particular, felt that African women are physically reconstructed and 'tightened up' to offer pleasurable intercourse to their masters whilst depriving themselves of pleasure, whilst Hosken (1979:247) is believed to have coined the term 'female genital mutilation' or sexual mutilation of females' as an attempt to attract immediate international attention and support to eliminate the practice. Many of them who have never been to Africa strongly pushed for this position, basing their knowledge on the stereotyping of gender relations based on Western models (Oba 2008:4, 5).

They also circulated more Western notions of sexuality and the clitoris, whilst local knowledge and motivations on the ground were largely shielded. International bodies such as the United Nations and its related agencies such as Amnesty International and World Health Organisation (WHO) have largely acted in line with feminist perspectives. The urgency is eradication and not contextual understanding. Secondwave feminism's knowledge has been explored extensively by stakeholders who address the practice on the ground 
leading to a lack of knowledge of other existing motivations on the ground in Ejagham. Their argument is considered skewed on various fronts in that women are primarily responsible for this practice amongst the Ejagham tribe and sexual deprivation is interrogated in this context (cf. Oba 2008:5; Pemunta 2011, 2012) as seen in the Ngbokondem and Moninkim beauty and sexual dances.

The Ngbokondem cult was a special women's association with extramundane activities which groomed women to be priestesses of Ndem spirit and at the same time as religious leaders of the land. The religious role these women occupied in Ejagham community and their varied interventions in the religio-political life could be described in Bediako's (1996:212) words as the first expressions of religious consciousness. They were 'the womb out of which Christianity was born' in Ejagham and Africa as a whole, as Maluleke (1997:10) puts it.

They were pre-colonial religious interventions that prepared people's hearts and paved the way for Christianity to easily take root in the land. Women who headed the Ndem cult intervened for the whole land as they communed with the spiritual realm to stop impending disasters, ward off evil, detect incoming attacks and ensure fertility and reproduction in land, and general peace and stability. They automatically became leaders of the land as their role gave them access to the spiritual and political gatherings as women who sit with men.

The sole criterion into this cult was Nkim e Nkim, which warranted a young woman (often the first daughter of a family) to be kept in seclusion for a period of 6 months to 2 years of intensive training in cult activities including fixing of her clitoris. The fixing of her clitoris became a mark of sexual maturation, status, power and identity that set her apart as leader amongst women. One crucial criterion for the cult to thrive was sexual stringency on the part of the priestesses after Nkim e Nkim to keep communion with the spiritual realm.

It was a precautionary measure that guarded the sexuality of the Ngbokondem (Talbot 1926:132). However, they could hardly keep the rule because as sexually active women they enticed and attracted the best breed of the land.

\section{Nkim e Nkim and sexual expressions in the Moninkim club}

Ejagham women question the notion of patriarchal domination and destruction of sexual pleasure by the absence of a clitoris. Even as fixed women, they have always experienced utmost sexual satisfaction (cf. Ahmadou 2004; Dellenborg 2004; Njambi 2011; Obermeyer 1999; Oyefara 2015). It is in the Moninkim dance club that Nkim e Nkim finds its sexual highest expression and fulfilment in the Ejagham community.

This is a dance club founded for young women to be groomed from adolescence to maturity. The dance bears the same name as its dancer. The name Moni-Nkim literally translated means Nkim citizen. It has two syllables, 'Mon' which means child and 'Nkim' which means a 'cut' to fix. Women described Moninkim club as an initiation and sexuality school (Nzegwu 2011:263) which trains young women to maturity on issues of sexuality, character building, home, marriage and society, with a chief identity marker being Nkim e Nkim. As such Moninkim means 'fixed one', that is a female child who has been fixed (Takon 2016).

As a female teenager, having reached the age of puberty, she is fixed after being schooled in character, home management and social morals expected of a worthy woman. It is the institution that preserves, promotes, presents and transfers traditional values and customs of the Ejagham people from generation to generation (Takon 2016). Only those who have been 'fixed' are qualified to be referred as such, to dance the dance and to belong to the club. It is believed that the clitoris hinders dance steps because when heated, it could either itch or rub between the sweaty thighs. The dance is so crucial to women's identity and sexual well-being that traditional herbal treatments are sometimes applied to women's legs to ease movement and gait. The dance and the Ndem club are as old as the practice of Nkim e Nkim.

The dance nurtures and displays beauty, body, sexuality and the pride of Ejagham woman in all her royal attributes and style. It is a queenly dance not like any other in the Manyu division. As a privileged royal club for women, it enhances femininity and empowers womanhood. Beauty and sensual captivation and entertainment are vital features. Moninkims are peculiar for their shape, grace, charm, articulate dancing skills, gait and body gesticulations, well-built hips, beautiful legs, pointed breasts, gap teeth (sometimes locally designed) and character, which keep men glued to them (Ashuntantang 2010:31; Nzegwu 2011). These internal and external qualities are peculiar to Ejagham women even today.

Nkim e Nkim as a sexual mark of maturation fulfils two roles in Monikim or Ndem dances; it denotes physical strength and sexual attraction. It accords women space to prove physical bravery and autonomy through their will to endure pain (cf. Njambi 2011:294). Women use this as bait to taunt men who often have no proper clue concerning their fixing. Aesthetically, from the inception of the training inside Nju Nkim by a senior Moninkim, the young Moninkim is massaged daily with locally fabricated beauty treatments such as camwood, white clay chalk and kernel oil. Her hair is braided with style, and she is taught bodily movements and gesticulations from swaying plantain leaves to the wideopen arms (wings) of flying birds and butterflies. She is taught how to 'tap and separate her legs in enticing ways, to shake the back, whilst at the same time twisting the tummy and scattering her waist and hips like boiling water', as described by Moninkim Polly Obi of Ayukaba (interviewed 29/01/2016). At a crucial Moninkim dance setting, this takes her audience into sensual frenzy and joy, something she herself shares as a sexual being. Nonetheless, these same 
sexual dance rituals and other practices of Ejagham women are laced with patriarchal strain, with women themselves playing major roles. This is what the study engages as triple patriarchy.

\section{The concept of triple patriarchy}

Upon observation of Ejagham women's specific struggle with patriarchy, the term triple patriarchy is coined out of Ajayi-Soyinka's (1993) double patriarchy, Oduyoye's (1995) triple suffering, Thiam's (1978:118) 'multiple jeopardy' and Ogundipe-Leslie's (1994:36) six mountains on African women's backs to attempt some understanding of their present state of suffering and complacency and their resistance/acceptance attitude, as Pemunta (2012:235) puts it. According to Ajayi-Soyinka (1993:162), African people experienced patriarchy by their subjugation through race and its colonial imperialistic politics. The experience of women in this subjugation was, however, different. Firstly, they were subject to indigenous patriarchy in their cultures before foreign domination.

Thiam (1978:118) uses multiple jeopardy to portray African women's plight in light of such global and home-based patriarchal violence. She specifically describes a situation wherein:

... [T] he black woman of Africa suffers threefold oppression: by virtue of her sex, she is dominated by man in a patriarchal society; by virtue of her class she is at the mercy of capitalist exploitation; by virtue of her race she suffers from the appropriation of her country by colonial or neo-colonial powers. Sexism, racism, class division; three plagues ... (p. 118)

Her exposition takes coloniality and cultural male domination into consideration just like Ajayi-Soyinka and Oduyoye. Nonetheless, they all leave out a vital aspect of African women's oppression, women themselves.

Ogundipe-Leslie (1994:27-36) is the African scholar who comes closest to this idea of triple patriarchy that pitches African women as agents in their own oppression. She describes six mountains of oppression meted on the backs of African women, namely, oppression from the outside (especially the ravages of colonialism), some African cultural traditions, the backwardness of the African woman, men, race and, lastly, the African woman herself (Ogundipe-Leslie 1994:36). She sees this last mountain as the most important and most aggressive because it consists of a woman fighting against her own self with forces such as negative criticism, fear, self-defeat, negative complex and so on, including romanticising culture. This operates when violence is done just to ensure the survival of an agency, a clique, a system, culture or dogma (Oduyoye 1995:33). Hence, whilst citing both external and internal factors of her oppression, Ogundipe-Leslie does not leave out the African woman as a contributing agent to her own pain. Amongst women, there are some who are more powerful and privileged to be close to power or the status quo than others; it is such who then initiate as the case in Ejagham.
In the modern era, Ejagham women who face coloniality and cultural male domination, in turn, oppress one another by exercising agency on themselves. This is done through complacency and silence over norms enforced in connection with some of their initiation practices which largely strengthen patriarchy. This phenomenon is labelled 'triple' as women participate in own oppression or suppression by commodifying certain cultural and sexual norms which oppress vulnerable women in their midst. Put succinctly, 'triple patriarchy' expresses the predicament wherein Ejagham women, who already suffer double domination from Western imperialism and cultural male domination, also participate in subjugating their kind through the manipulation of rituals and rites.

Oduyoye (1995:154) throws some light on how this happens. She explains that patriarchy generally privileges a few women who stand to sustain the structure by creating a form of agency that ensures that their kind is constantly toeing the patriarchal line. Women uphold certain patriarchal rites as passive victims because of certain life-giving aspects that they seek to protect (Oduyoye 1995:15). This form of patriarchy is prevalent within some women initiation rites in Eagham community.

\section{Women's initiation rites and triple patriarchy}

\section{Nkim e Nkim as 'bottom power' insurgency within a context of impoverishment and empire}

The present capitalist schemes operative within Nkim ('Female genital mutilation') culture in Ejagham could enable one to see Ejagham women as lumpen-proletariat in Mosala's $(1989: 9,10)$ words. Drawing inspiration from the book of Micah, Mosala describes lumpen-proletariat as a group that has been reduced to base living through poverty made possible by consumerism and dispossession by the exploitative bureaucracies of the day.

These dispossessed include the landless peasants, labourers, unemployed, petty criminals, bandits (Mosala 1989:10) and other strugglers whose lives have been reconditioned to sometimes include petty dubious activities. In the context of Nkim e Nkim and empire as operative today in Ejagham, women are severally lulled by funding agencies that mask exploitative interests and by frightening impoverishment through marginalisation to indulge in petty dubious schemes to survive. This provokes what Boesak (2017:62) discusses as consumerism that 'encourages commercialized cultural and religious practices'. It exposes attitudes of lack of commitment in a people's life, even on salient issues such as human sexuality, spirituality, education and so on, and unleashes the struggle for survival that thrives even at the expense of the people's practices of identity (Boesak 2017:62).

An example to illustrate the above phenomenon within the Nkim culture is seen in Ejagham women's acceptanceresistance syndrome, as Pemunta (2012:234-237) describes it. 
It reveals a phenomenon wherein local activists and NGOs on the ground introduce Western-funded micro-developmental projects aimed at fighting 'female genital mutilation'. These projects are supposed to drift women's interest away from Nkim e Nkim towards alternative ventures that could fight poverty. Because local activists portray the notion that persistence in the practice is the result of poverty and backwardness, the best possible means of eradication posits the introduction of petty funded aid schemes or financial tokens to deviate women's attention from Nkim e Nkim.

However, closer engagement with women on the ground reveals multiple complications and contradictions with these methods. Firstly, the acceptance/resistance contradiction comes to light here as women accept the tokens that are handed and make overt promises to stop the practices, but then continue with their lives as usual after such overt commitments whilst Nkim culture thrives on. Such influence by financial gains renders a simplistic view of the practice to the NGOs and funders of field projects. At such moments, the fixers and Moninkims would be summoned to give vital information needed by the organisations. Pemunta (2009:7, 2012:235) reports the following:

... [O]nce the discussion shifted to female circumcision, they expected payment. Intervening NGOs have unwittingly made them realize that 'female circumcision is money'. This has been done partly through the lavish entertainments that often characterise anti-female circumcision activism. Anti-female circumcision NGOs usually share food and drinks at the end of every campaign session, workshop or conference. The impression often created by these events - which are often orchestrated to lure people to come out in great numbers so that photographs can be taken and presented to funders to attract more funds - is that female circumcision is closely associated with money. (Ajayi-Soyinka 1993:162)

Usually, once such event is over, life returns to normal. The question that preoccupies one here is what image are these women painting of Nkim and what impact are they making of Nkim culture by succumbing to such periodic temporal financial gains? This question particularly begged for attention on the 28 February 2016, when the Canadian ambassador's representative visited the area to put 'final end' to 'female genital mutilation' in the area. The researcher captured a particular scene in a brief sketch presented to the audience which began to throw some light on the shifting positions of women in Nkim discourses. Some fixers were in the process of fixing a young woman. One of the fixers stepped forth to explain why and how they performed Nkim. Their reason (or pseudo reason) was that they made their daily living from the practice. They did this through forcefully constraining young girls and women to the practice. Then one woman stepped forward and told the representative in Pidgin (broken) English that 'Mr Francois, you get for helep we women them so that we fit find other small market them bekindo'am, and stop this practice weyeh di hot we girl pikin them'. Literally translated, it means: you have to help us financially so that we can deviate from this practice that hurts our young women, so that we can instead undertake petty businesses.
From the look of things, the funds were disbursed as one could detect from the back door fights that ensued later. Arguments broke out as to how the 'proceeds from Canada' were distributed. Some local women who felt cheated accused the NGO agents of 'using' them. They vowed to boycott subsequent events organised by them. One of the women addressed the head of the NGO thus:

... $[W]$ hen you people have an issue you come and take information and it would just end like that. Like what you are doing now. When you get what you want, you go and we never see you again. Finish with us, settle everything now. (Ajayi-Soyinka 1993:162)

Nkim has become the new trade where women use their bottoms to make money; this time not through sale of sex as in prostitution, but through sale of fixed genitals' where a few women arrange to subject others' genitals in front of foreign cameras for foreign consumption.

As a preoccupying phenomenon, Marc Ela (1994:141) cautions African peoples to refuse these crumbs that the West sit in their comfort and throw to poor black people to enslave them even further. His appeal is true, considering that these microaid schemes are, for the most part, economically and politically motivated farce that generally serves a few interests and satisfies brief hunger whilst overlooking the people's and especially women's real needs and daily struggles against poverty, oppression, marginalisation and degradation.

The implications that such scenes have on culture and spirituality is that they paint violent and oppressive pictures of Nkim e Nkim to the outside world which are contrary to real motivations on the ground. These views are taken over by media houses, newspapers, articles, journals and newsagents at home and abroad, and broadcasted with pictures of Ejagham women and community. They, later on, return home to haunt the very women who made them and the entire community, as they are looked upon as barbaric. The quest for gains then is taking Nkim discourses deep into the realm of 'empire' referred to by Plaatjies van Huffel (2011:2) as a 'patriarchal top-down system' that plunges the oppressed into deeper misery whilst exalting the real oppressor (foreign funders).

These manifestations of empire are all combined and are operational in Nkim discourses as they unfold today through decimation of culture which ends up in enslavements, destructive self-interest, greed and worship of money, propaganda, colonisation of consciousness, a spirit lacking compassionate justice and showing contemptuous disregard for the gifts of creation and the household of life (Plaatjies van Huffel 2011:2). Nkim discourses are fast turning into bottom (genital) market, which Boesak $(2017: 63,69)$ sees as the most successful religion of all time, especially in the current era of globalised neoliberal capitalism. It commercialises culture, colonises consciousness and blunts the conscience (Boesak 2017:64) whilst taking advantage of the poor and miserable, exposing them to even superior forms degradation. 
In proposing to supply women with money for petty businesses to eradicate Nkim, could Canada not be seen as concealing its real intent, that is, the continuation of empire with schemes that gear towards deliberate dominations and subjugations and even eradications? (Boesak 2017:81, 82). It is in this light that Oduyoye (2001:12) urges oppressed people to peruse with suspicion, and if possible, 'fence off' schemes of liberation that come from the oppressor. Continuous marginalisation and degrading poverty cause Ejagham women to enter into partnerships of convenience and 'sign pacts of death' by commercialising and even trading off Nkim e Nkim which is the very core of their identity and personhood. Could they then not be placed within the spectrum of what liberation theology detects as an expression of the trenches of impoverishment? Is their situation not sustained by the contradictions of ethical questions and paradoxes that arise as a result of the perpetuation of impoverishment and the stereotyping of a people by the powerful within and without African cultural realm? Could their commercialisation of culture and degradation of self not be the expression of the ugliness of the cross which is often hidden by the sophistications of Western forms of knowledge and civilisation? (cf. Cone 2011)

Oduyoye's (1995:82) advice could be endorsed here to check double standards within Nkim discourses as well as suspect the varied funded projects of solidarity that constantly view African women as objects than subjects.

She advises that only when foreign interventions are thorough and empathetic do they become valuable expressions of solidarity. It is at this juncture that we suggest that Ejagham women cannot vindicate themselves from the patriarchal violence through the double-faced picture being painted of Nkim e Nkim as rite and ritual that oppresses women when at their personal level they hail it as a worthy mark of sexual maturation and identity. This is because they are fully aware that they are trading Nkim cheaply and they could as well evaluate the ridicule this makes of them and their kind at home and abroad. Could their shifting attitudes not be the reason for the complications and dilemmas that hinder suitable solutions to truly address Nkim e Nkim in Ejagham community? Another initiation practice that manifests such attributes is the Nkekwet (widowhood hood) rites and rituals.

\section{Nkekwet (widowhood) rites and triple patriarchy}

Kwok (2005:7) has cited culture as one of the crucial elements that shapes and influences African women's lives. It is the tool they use to understand and interpret their realities, specifically in relation to the Bible (Oduyoye 2001:12). However, Kwok (2005:7) notes that culture could be a doubleedged sword in that whilst it makes available a communal identity and sense of belonging to women, it could be manipulated at the same time and used as a tool of domination. It is in widowhood rites that triple patriarchy gets to the peak of its manifestation. As old as can be,
Ejagham people faithfully mourn their dead. The mourning of a spouse is peculiar because it is the relationship with the closest sexual spiritual bond in the living community. However, in the Ejagham clan, one can easily identify widows but not widowers go through certain rites that are socially designed for them. And women often endeavour to follow these rites to the letter whilst men just flaunt over them. It is at this point that one understands triple patriarchy. Widowhood rites sail from dressing through comportment, length of mourning period and remarriage.

For decades, the Ejagham clan has been best known for the 'black cloth' tradition wherein widows wear specially sewn pure black dresses to mourn their dead husbands. In the early days, it was just one gown for the elaborate mourning period, some of which could last from 6 months to 2 years. Today white dresses and fabric are tolerated. In addition, widows are expected to comport in defined ways and failure to do so attracts scorn and sometimes fines from family members and friends alike. Such comportment includes constant wailing to mourn the deceased. A widow who does not wail is seen as not having loved her late husband and is now happy that he is gone. In addition, she must not greet people with her hand or look happy, and her speech must be limited throughout the funeral period. She carries her right hand upon her shoulder when going around, sleeps on the floor and eats sparingly. She drinks no alcohol during this period and puts on no make-up. She also baths sparingly and must not attend any parties until the mourning period is over.

Widowhood rites are typically women's things and 'punishment for them as well' as Pa Dickoben (interviewed 25/03/2017) of Nkpot puts. Because it is assumed that men will die first and women will stay longer to enjoy life, widowhood rituals are carefully promoted as a means of consolation to living men and husbands. Throughout the mourning period, the widow avoids contact with men, especially sexual intercourse. This would be considered an abomination for a widow in mourning as it could signify lack of love for her husband; she may even have plotted his death. In some cases, sensual relations are totally banned for the widow and non-compliance on her part may be fatal (Weinger \& Akuri 2009:54). On the contrary, a widower outwardly mourns for a fairly shorter period, mostly during the time when his wife is in the mortuary and on the day of the funeral.

Some women revealed that their present husband had treated them as girlfriend fairly shortly after their wife's death. Such girlfriend who soon replaces the wife could be sitting somewhere in the crowd right at his wife's funeral.

The implementation of widowhood rituals is strictly enforced by women - mostly fellow widows, mothers-in-law / sistersin-law, female siblings and female relatives of the deceased. Noteworthy here is the fact that women do not usually view their actions as domination but as agency and empowerment. Silence and complacency are major features in the thriving of 
this practice. Often, men have the authority to stop or reduce the strain of these rites.

Some do, but others claim non-interference. Mrs Ayuk Abbeamagha states the following:

\begin{abstract}
... And you know as Kembong is like this with seventeen or eighteen quarters, every quarter has their own way to treat widows. Some are harsh, some are a bit mild especially when it comes to the demand of articles to give the in-laws. Mine was mild because I had a good brother in-law who kept telling them not to molest me, but to make things easier for me. (AjayiSoyinka 1993:162)
\end{abstract}

Patriarchy is most visible in this ritual because men understand clearly what is going on, but profess less concern with excuse that it is women's affair. It is only when the rules are flawed that one discovers the actual people in control. In cases where a widow is hated by her in-laws, they may strip her bare of dignity, property and worth, as she is molested to nothingness. In such a case, a widow becomes what Oduyoye (1995) refers to as 'a disinherited species', one who is treated shabbily to ensure her dehumanisation.

In Ejagham community, some women make huge benefits through the varied ritual stages, that is, the cleansing/ bathing part, the shaving of hair, the hitting of the knife on the head, the hoeing of the farm, the visitation/selling in the market, preparation of food for the in-laws and the funeral celebration (black/sackcloth removal). It is a frightening paradox when some women consider that their lives have literarily come to an end at the death of their husbands. This ought to be the period when women get the deepest psychological support and comfort from their community. As a lament against this form of domination, Ma Ebanghachu of Ndekwai had this to say:

'Can you treat yourselves well? Instead when you see a woman in pain you want to crush her. I do not know why we keep on fighting ourselves. So that is it, whether we talk until tomorrow ... What are you saying, woman! And that is why the man remains up [she laughs]. We are the ones who are doing this to ourselves.' (Interviewed 27/01/2016)

According to her, women have remained the very source of their own pain. With the recent increase in the death rate in this area and the biting impoverishment, widowhood rites are fast becoming lucrative enterprises for women and men (behind the scene), which venerates man, dead or alive, but suppresses their fellow woman to nothingness.

\section{Implications of triple patriarchy on Ejagham women's liberation}

Implications could be noticed in the area of sexuality, health and identity, spiritually or theologically. Sexually, Nkim culture has attracted pejorative labels of Ejagham women. Some Ejagham women have been perceived as 'free givers', 'easy going', 'sharers', ashawo, akpara, awalawala and nyangi signifying sexually active nature which has made them experienced brokenness of their bodies along the decades. They have also been labelled violent, barbaric and mutilators, indicating violent behaviours. In all these, they are an indication of what Madipane Masenya (2012:128) describes as deviant or anomaly to many. Socially, such stereotypic labels affect their generation in the Cameroonian context. Ejagham women's struggles with broken image and labels are detrimental to women's spirituality, identity and sexual well-being.

In addition, the controversiality exercised by women within Nkim culture promotes labelling, and some Ejagham women comply with this because of biting impoverishment, ignoring the destruction this has on women's sexual image. Ethically and spiritually, no people would trade their genitals before cameras for desperation, for even poverty has dignity.

In the present context of law and police surveillance, triple patriarchy still ensures the survival of Nkim e Nkim.

Women set strict rules and cover each other's tracks in spaces where the practices are performed. No one reports to the police except a major eventuality occurs. Hence, there is a mutual understanding in the agency that defies surveillance. Nonetheless, the haemorrhagic effects that sometimes ensue from intractability are health concern in the area for the lives of women. It is at this point that one asks with Maluleke (2018) if it is worth it to maintain Nkim in such secrecy if it puts women's lives at risk?

Again, persistence may only portray the strong affiliation to culture that stakeholders still take for granted. One of such affiliation is the strength of initiation itself on Ejagham women's spirituality. One ponders on the place of initiation practices in Ejagham women's religious-cultural world seeing that the spiritual and physical universe is still conceived by them as joint, which causes a constant mélange of cultural and Christian forms of worship. Adherents of the Nkim culture are the same fervent members of the worshipping community who understand the importance of certain Christian initiation rites only through their foreknowledge from cultural practices. This provokes important questions such as: is it possible for Ejagham women to erase their initiation practices as suggested by stakeholders, and successfully maintain solely Christian rites such as baptism and others as their sole spiritual identity. In other words, would the spirituality of Ejagham/black African women be complete without initiation of their practices?

Theologically, initiation practices are the very foundations of people's spirituality, from which they make meaning of spiritual universe. A salient implication for this study is that if women's initiation practices are by any means eradicated, they may not have the base to help them grasp the full meaning of Christian initiation rites as we have them too. Ejagham women bring something to the table through which Christianity initiates a dialogue for the soul. Initiating dialogue with culture and especially the life-giving aspects of Nkim culture can be a 
way forward whilst debunking the ills. It is only through such dialogical approaches that promise of true and genuine contributions could be made to address the future of sexuality and spirituality through Nkim culture in Ejagham land.

\section{Conclusion}

In this article, we have endeavoured to portray the complexity of the triple-faced phenomenon which portrays Ejagham women as resistant and agents of patriarchal domination. The aim is to engage their struggles within a declining cultural realm and degrading impoverishment to identify with an African identity practice, whilst at the same time expose their compliance with patriarchy. The later stance has fortified Oduyoye's (1995:97) exclamation, which says that 'women against women is part of our heritage'. Widowhood rituals and the current controversiality within Nkim culture are glaring examples of triple patriarchy.

The study advocates a new approach altogether; rather than the old tactic of labelling, condemnation, financing and surveillance, African cultural practices such as Nkim e Nkim have aspects to 'fine-tune' in them; space should be given for questioning and fine-tuning rather than eradication, which may erode the very foundations of a people's culture and hence their being and identity.

\section{Acknowledgements}

Great thanks go to the lord God Almighty for his wonderful love and mercy bestowed on authors to carry on this journey thus far. The authors thank the Presbyterian Church in Cameroon for granting them the opportunity to pursue this study. T.J.O.E.B.-W. thanks his supervisor, Prof. Vuyani Vellem, for his great mentorship, his tireless efforts, immense wisdom and the care and support. The authors also thank the University of Pretoria for granting them the opportunity to study, for the scholarship offered and academic resources made available as well as library facilities.

\section{Competing interests}

The authors declare that no competing interest exists. They declare that this article is their own original work. All the works of other authors used in the study have been duly acknowledged and referenced accordingly.

\section{Authors' contributions}

Both authors made immense and equal contributions to the realisation of this work.

\section{Ethical consideration}

This article followed all ethical standards for a research without direct contact with human or animal subjects.

\section{Funding information}

This research received no specific grant from any funding agency in the public, commercial or not-for-profit sectors.

\section{Data availability statement}

Data sharing is not applicable to this article as new data were created or analysed in this study.

\section{Disclaimer}

The views and opinions expressed in this article are those of the authors and do not necessarily reflect the official policy or position of any affiliated agency of the authors.

\section{References}

Ahmadou, S.F. \& Richard, A.S., 2009, 'Disputing the myth of the sexual dysfunction of circumcised women: an interview with Fuambai S. Ahmadu', Anthropology Today 25(6), 14-19.

Ajayi-Soyinka, O., 1993, 'Black Feminist Criticism and Drama: Thoughts on Double Patriarchy', Journal of Dramatic Theory and Criticism, 7(2), https://journals. ku.edu/jdtc/article/view/1875/1838.

Anne, K., 1968, The Myth of the Vaginal Orgasm, New England Free Press, Boston, MA. Ashuntantang, J.B., 2010, A basket of flaming ashes, Langaa Research and Publishing $\mathrm{CIG}$, Makon, Bamenda.

Bayen, B.P., 2016, 'The effects of female genital mutilation in Cameroon: Case study Ejagham community of Eyumojock sub-division', Unpublished Masters thesis, Master's in Peace and Development Work, Department of Social Studies (4FU42E).

Bediako, K., 1996, Christianity in Africa: The renewal of a non-western religion, Orbis Books, Maryknoll, NY.

Boesak, A.A., 2017, Pharaohs on both sides of the blood-red waters: Prophetic critique on empire: Resistance, justice, and the power of the hopeful Sizwe: $A$ transatlantic conversation, Wipf and Stock Publishers, Eugene, OR.

Cone, J.H., 2011, The cross and the lynching tree, Orbis Books, Maryknoll, NY.

Daly, M., 1978, Gynaecology: The meta-ethics of radical feminism, Beacon Press, Boston, MA.

Dellenborg, L., 2004, 'A reflection on the cultural meanings of female circumcision: Experiences from fieldwork in Asamance, southern Senegal', in S. Arnfred (ed.), Rethinking sexualities in Africa, pp. 79-96, The Nordic Africa Institute, Uppsala.

Ela, J.M., 1994, 'Christianity and Liberation in Africa', in R. Gibellini (ed.), Paths of African theology, pp. 136-153, Orbis Books, Maryknoll, New York.

Hamilton, A., 2013, A general overview of the Kenyang language, https:// princehamilton. blogspot.com.

Hosken, F., 1976, 'Women's international network news', in M. Daly (ed.), Gyn/ ecology: The metaethics of radical feminism, vol. 2, no. 1, pp. 169, 445, Beacon Press, Boston, MA.

Hosken, F., 1978, 'The epidemiology of female genital mutilations', Tropical Doctor 8 , 150-156.

Hosken, F., 1979, The Hosken report: Genital and sexual mutilation of females, Women's International Network News, Lexington, MA.

Koedt, A., 1968, The myth of the vaginal orgasm, New England Free Press, Boston, MA.

Koedt, A., 1973, 'The myth of the vaginal orgasm', in K. Anne, L. Ellen \& R. Anita (eds.) Radical feminism, pp. 198-207, Quadrangle Books, New York.

Kwok, P., 2005, Postcolonial imagination and feminist theology, SCM Press, United Kingdom

Machera, M., 2004, 'Opening a can of worms: A debate on female sexuality in the lecture theatre', in S. Arnfred (ed.), Rethinking sexualities in Africa, pp. 157-172, Almqvist and Wiksell Tryckerie AB, Sweden.

Maluleke, T., 1997, 'Half a century of African Christian theology: Elements of the emerging agenda for the twenty-first century', Journal of Theology for Southern Africa (99), 4-23.

Maluleke, T., 2018, 'Price we pay for toxic masculinities', The Sunday Independent viewed 16 August 2018, from https://www.iol.co.za/sundayindependent/ dispatch/price-we-pay-for-toxic-masculinities-15771392.

Masenya, M., 2012, 'Dripping nails, desire and polygynous partnerships: Navigating women's stories in Gen 29-30 through African Love Song(s)', Thoelogia Viatorum 36(1), 125-139.

Mosala, I.J., 1989, Biblical hermeneutics and black theology in South Africa, Eerdmans Publishing Company, London.

Njambi, W.N., 2011, 'Irua Ria Atumia and anti-colonial struggles among the Gikuyu of Kenya: A counter narrative on female genital mutilation', in O. Oyewumi (ed.), Gender epistemologies in Africa: Gendering traditions, spaces, social institutions, and identities, pp. 179-198, Palgrave Macmillan, New York.

Nzegwu, N., 2011, 'Osunality or African eroticism', in S. Timale (ed.), African sexualities: A reader, pp. 253-270, Pambazuka Press, Cape Town

Oba, A., 2008, 'Female circumcision as female genital mutilation: Human rights or cultural imperialism?', Global Jurist 8(3), viewed 13 March 2017, from http:// www.bepress.com/gj/vol8/iss3/art8. 
Obermeyer, C.M., 1999, 'Female genital surgeries: The known, the unknown, and the unknowable', Medical Anthropology Quarterly 13(1), 79-106. https://doi.org/ 10.1525/maq.1999.13.1.79

Oduyoye, M., 1995, Daughters of Anowa: African women and patriarchy, Orbis Books, Maryknoll, NY.

Oduyoye, M., 2001, Introducing African women's theology, Sheffield Academic Press, Britain.

Ogundipe-Leslie, M., 1994, Re-creating ourselves: African women \& critical transformations, The Africa World Press, Inc., Trenton, NJ.

Onor, S.O., 2017, 'Decolonizing Nigerian women: A historical necessity', International Journal of History and Philosophical Research 5(3), 24-35, viewed 15 August 2018 , from http://www.eajournals.org/wp-content/uploads/Decolonizing-NigerianWomen-A-Historical-Necessity.pdf.

Oyefara, J.L., 2015, 'Female genital mutilation (FGM) and sexual functioning of married women in Oworonshoki Community, Lagos State, Nigeria', African Population women in Oworonshoki Community, Lagos State, Nigeria', African Population
Studies 29(1), 1527-1541, viewed 30 April 2017, from http://aps.journals.ac.za.

Pemunta, N.V., 2009, 'Multiple identities: Gender, power and the production of anthropological knowledge', Anthropology Matters Journal 11(1), 1-13.

Pemunta, N.V., 2011, Health and cultural values: Female circumcision within the context of HIV/AIDS in Cameroon, Cambridge Scholars Publishing, Cambridge.
Pemunta, N.V., 2012, 'Resistance to the eradication of female circumcision and the political economy of under-development in Cameroon' Gender, Technology and political economy of under-development in Cameroon', Gender, Technology and
Development 16(2), 223-245. https://doi.org/10.1177/097185241201600205

Plaatjies van Huffel, M.-A., 2011, 'Patriarchy as empire: A theological perspective', Studia Historiae Ecclesiastae 37(Suppl.), 259-270.

Ruel, M., 1969, Leopards and leaders: Constitutional politics among a cross river people, Tavistock Publications, London.

Takon, N.N., 2016, 'A research on Moninkim dance of the Ejagham people of Nigeria and Cameroon', viewed 22 October 2018, from http://moninkim.blogspot. com/2016/06/a-research-on-moninkim-dance-of-ejagham.html.

Talbot, P.A., 1926, The peoples of Southern Nigeria: A sketch of their history, ethnology and languages, with an account of the 1921 census, Oxford University Press, London

Thiam, A., 1978, La parole aux negresses: Black sisters speak out: Feminism and oppression in Black Africa, Editions Denoel, Paris.

Weinger, S. \& John, A., 2009, 'Cameroonian women's perceptions of their health care needs', Nordic Journal of African Studies 16(1), 47-63, viewed 23 October 2016, from http://www.njas.helsinki.fi/pdf-files/vol16num1/weinger2.pdf.

Wipper, A., 1985, Riot and rebellion among African women: Three examples of women's political clout, Working paper no. 108, University of Waterloo, Ontario. 